\section{Ambroz Tudor}

Uprava za zaštitu kulturne baštine, Konzervatorski odjel u Splitu

Izvorni znanstveni rad / Original scientific paper

UDK / UDC: 728.84(497.5 Hvar)

25. 9. 2013.
Prilog poznavanju izvornog izgleda ljetne palače Paladinić na hvarskoj Pjaci

Ključne riječi: Pjaca, Paladinić, kasna gotika, Domenico Gazzari, simetrizacija pročelja Key words: Piazza, Paladinić, Late Gothic, Domenico Gazzari, symmetrizing of the front of the building

Autor pojašnjava prostorni kontekst u kojem se u drugoj polovini 15. stoljeća podiže donja palača Paladinić. Također donosi poznate povijesne podatke o obitelji Paladinić kao i podatke o događajima vezane uz palaču. Najvažniji doprinos je publiciranje nacrta iz 1869. godine, u precrtu iz 1925. godine, gdje se donosi izvorni izgled palače prije velikog zahvata iz 1868. i 1869. godine u kojem je radiran velik dio izvornog stanja palače.

Donja ili ljetna palača Paladinić prva je poznata stambena građevina na hvarskoj Pjaci. ${ }^{1}$ Ambicioznošću svoje arhitekture iz druge polovine 15. stoljeća započela je urbanističkoarhitektonski proces pretvaranja velike poljane obrubljene vrtovima u gradski trg. Palača je sagrađena na prostoru vrtova pred južnim potezom gradskih zidina, prostoru koji je svojim hortikulturnim osobinama toliko sličan krajoliku europskih, posebice sredozemnih gradova gdje od kraja 13. stoljeća uz njih nastaju brojni vrtovi, vinogradi i oranice. ${ }^{2}$

U vremenu njezine gradnje još nije postojalo značajno razlikovanje između prostora Pjace i Dolca, poljane ispred i u zaleđu katedrale. Dapače, tijekom većeg dijela komunalne povijesti grada ovi su prostori doživljavani kao jedinstven prostor s katedralom i biskupskom palačom na središnjem dijelu. Dokumenti 15. i 16. stoljeća za taj prostor često znaju koristiti hrvatsko ime Dolac, ili lučiti Gornji i Donji Dolac, s obzirom na to je li predmetni lokalitet smješten istočno ili zapadno od katedrale. ${ }^{3}$ Tek od kraja 17. stoljeća, do kada je Hvar uspio završiti proces pretvorbe četiri i pol tisuće kvadratnih metara velike poljane između katedrale i mora u definirani gradski trg, prostori Pjace i Dolca počet će se razlikovati kao dva različita gradska prostora.

Kako je prije spomenuto, doživljaj jedinstvenosti ovih prostora omogućavala je prije svega identičnost njihovih pretežitih prostornih osobina; i Pjaca i Dolac bili su ispunjeni vrtovima. Najraniji spomen vrtova na današnjoj Pjaci datira iz 1311. godine kada biskup Gabrijel dobiva pravo na kuću i vrt uz crkvu sv. Marije u Hvaru, poslije katedralu. ${ }^{4}$ Krajem 14. stoljeća prostor Pjace i Dolca ispunjen je vrtovima. Katastik komune iz oko 1380. godine donosi spomen brojnih vrtova ispod gradskih zidina, prope murum communis, kod bunara, prope puteum, ili kod gradskih vrata, prope portam civitatis, što je sve dakle prostor buduće Pjace. ${ }^{5}$ Brojnost vrtova, kao i njihov smještaj govori da je Hvar krajem 14. stoljeća grad okružen vrtovima.

Najvažniji dokument za poznavanje srednjovjekovnog izgleda Pjace je nedavno objavljeni zahtjev arhiđakona Pavla Paladinića iz 1459. godine u kojem od hvarskog kneza traži da iskoristi svoje pravo dodjele gracija za podizanje kuća i skladišta te zaustavi daljnju gradnju na Pjaci. ${ }^{6}$ Među argumentima najvažnija je potreba za prostorom procesija, no važan argument je i veličanstvenost pogleda s obale na tada novosagrađeno pročelje katedrale s brdima u pozadini, što upozorava na razvijeni renesansni osjećaj za ljepotu pejzaža kao mjesta ovoga svijeta. ${ }^{7}$ Jasno je da zahtjev arhiđakona Paladinića nastaje u strahu Kaptola da će kuće zapuniti prostor Pjace i zatvoriti katedralu, a njegovo prihvaćanje od strane komunalnih vlasti zapravo je stvorilo ovaj trg. ${ }^{8}$ 
Paladinić sugerira knezu da izgradnja treba ostati u dotada dosegnutim granicama, te mu stoga poimenice opisuje vrtove i građevine na Pjaci. Jedini zatvoreni volumeni zgrada koji su se uzdizali nad poljanom su katedrala s biskupijom, dućani uz sjeverno pročelje arsenala i crkva Svih svetih s hospicijem (»spedale«) na središnjem dijelu sjeverne strane poljane, u neposrednoj blizini buduće palače Paladinić. Sve ostalo su vrtovi. Poimenično se spominju vrtovi plemića Luke Piretića i Andrije Dobroslavića, dok su ostali spomenuti kao ostali vrtovi, "altri orti li contigui «, ili vrtovi drugih osoba, »orti de spetial persone «. ${ }^{9}$ Nešto prije, 1434. godine spominje se vrt drevne obitelji Slavogosti na Pjaci pored jednoga komunalnog vrta. ${ }^{10} \mathrm{U}$ jednom od ovih vrtova rasla je i velika palma koja je glavnim gradskim vratima dala ime »Porta del Datollo«, a koju prikazuje i najstarija veduta Hvara, Conrada von Grünemberga iz 1486. godine. ${ }^{11}$ Godine 1475. Andrija i Antun de Cholinis spominju se kao vlasnici vrtova na općinskom trgu, dakle Pjaci. ${ }^{12}$

Poznati su vlasnici vrtova uz nekadašnju crkvu Svih svetih, građevine koja je tek nekoliko metara bila udaljena od istočnog zida palače. Marin Hektorović, otac Petra Hektorovića, kupio je kuću na zidinama i dio vrta od Petra Bartučevića 1494. godine, ${ }^{13}$ a 1505 . godine i drugi dio vrtova na osnovi duga od 30 zlatnih dukata od Katarine i Markezine, kćeri bračkog plemića Leonarda Mišetića. ${ }^{14}$ Vrtovi su se nalazili upravo ispred njegove kuće na gradskim zidinama. Važan je podatak da Marin Hektorović traži od kneza dozvolu za podizanje odrine na drvenim stupovima u ovim vrtovima, a što najvjerojatnije znači da su kuća i vrtovi bili povezani vratima u gradskim zidinama, odnosno da je Marin Hektorović u drugoj polovini 15. stoljeća uz Pjacu ostvario stambenu cjelinu naglašenih ladanjskih obilježja. ${ }^{15}$ Pjesnik Petar Hektorović naslijedio je od oca ovu cjelinu, a u oporuci iz 1560. godine spominje je kao »la mia casa, existente sopra le mure de la cittá di Liesena tra la casa de quelli de Paladini et quelli de Gazzari ... il mio horto, qual e sotto le mure dela terra et in parte sotto la casa preditta... « ${ }^{16}$

Povijest obitelji Paladinić tek je djelomično poznata. Obitelj je ogranak roda Lucića i s njima dijeli identičan grb. Naime, heraldička praksa hvarske komune bila je da novi ogranci ne formiraju inačicu osnovnog grba nego da zadržavaju izvorni grb. Najstariji poznati predstavnik je Roland Paladinus koji se spominje 1321. godine, a imao je sina Nikolu i unuka Dujma. Dujmov sin Nikola imao je sinove Dujma, najstarijega poznatog hvarskog povjesničara koji je ostavio zapise iz 1416. godine, arhiđakona Pavla, Jakova i Luku. Nikola Paladinić, Jakovljev, proglašen je 1474. godine vitezom Svetog Marka za vrijeme dužda Nikole Marcella. Zanimljivo je da se u izvornoj duždevoj povelji od 8. siječnja 1476. godine koristi hrvatski oblik prezimena "Paladinich", a na isti način ih naziva i H. Lucić početkom 16. stoljeća. Tom je prigodom dobio zlatni plašt i zlatnu ogrlicu zbog hrabrog suprotstavljanja turskoj floti. ${ }^{17}$ Isti je
1482. godine oslobođen svih javnih radova a pravo je bilo nasljedno. Podvig Nikole Paladinića bio je toliko značajan da je »na vječnu uspomenu naslikan čak u mletačkoj (duždevoj) palači«. Riječ je o njegovoj pobjedi protiv turskog brodovlja kod Rodosa 1474. godine, a podatak o slici u Duždevoj palači potječe iz pisma u kojem se opisuje jedan od najkrvavijih događaja bune pučana. Godine 1514. u hvarskoj je Komunalnoj palači ubijeno dvadeset plemića koji su se tamo sklonili, među njima i Nikolin sin Toma, koji je tada sasječen $i$ »bačen s balkona na trg izvan grada", dok je njegov otac toliko zadužio Veneciju da su njegova djela, kako je prije spomenuto, oslikana u Duždevoj palači. ${ }^{18}$

Nedavno je otkriveno da je Tomin brat Pavao Paladinić služio knezu Federiku Aragonskom u Napulju te da mu je 1496. godine posvetio i poklonio svoj kanconijer stihova na latinskom i talijanskom jeziku. Lijepo ukrašeni renesansni kodeks danas se čuva u Veneciji. ${ }^{19}$

Paladinići izumiru sredinom 16. stoljeća, a njihovu su imovinu, po ženskoj liniji, naslijedile trogirske obitelji Lučić, Čipiko i Andreis. ${ }^{20}$

Gradnju ljetne palače Paladinić zasigurno treba povezati $s$ vitezom Nikolom Paladinićem i njegovom braćom, a samu gradnju datirati u drugu polovinu 15. stoljeća.

Važan izvor za poznavanje povijesti gradnje ljetne palače Paladinić je spor oko gradnje manje kule uz njezin sjeveroistočni ugao koji se zbio između poznatog pjesnika Petra Hektorovića i Frane Paladinića. Kako će se vidjeti, njihov spor iz 1524. i 1525. godine u suštini se vodi oko činjenice da Paladinić svojom gradnjom umanjuje ladanjska svojstva Petrove hvarske kuće, a s druge strane povećava ista svojstva svojeg sklopa. Već u prvoj tužbi knezu i providuru Petar Hektorović jasno kaže: »... nego i moje navlastito mjesto i zid moje kuće sa zapadne strane zaklanjajući mi pogled na luku i druge ugodnosti, podižući tu gradnju s lukovima i otvorima (con volti et cave) naslanjajući se na gradske zidine, svodeći ih na svoje potrebe za komoditet vlastite kuće (...) što mi zaista šteti kući, s ciljem da je napustim, quum fetor et dolor interimat homines et sunt de maximis prosternentibus virtutem... $\|^{21}$

Doista, istočni dio završnog kata južnog pročelja kuće Petra Hektorovića raščlanjen je ložom koja je podignuta na dva zidana ugaona stupa. Parapetni zid lože zaključen je profiliranom poklopnicom. S obzirom na jednostavnu, zaobljenu profilaciju poklopnice i posve jednostavne ugaone stupove može se pretpostaviti da je loža podignuta do kraja 16. stoljeća. Iako nepostojanje čvršćih uporišta ne omogućava preciznije datacije, moguće je kako je bila podignuta već za života Petra Hektorovića, koji je, kako se vidi, toliko cijenio pogled sa svoje hvarske kuće.

U dokumentima spora koji su dosada objavljeni doista se nalazi cijeli niz pokazatelja koji govore koliko je vlasnicima kuća uz hvarsku Pjacu početkom 16. stoljeća stalo do pogleda, zraka ili svjetla. Raniju pritužbu o zatvaranju 
pogleda Petar Hektorović dalje razvija u pismu knezu iz jeseni 1524. godine kada u 10 točaka izlaže svoje tužbe, a jedna od najvažnijih je: »Jer mi je zaklonio pogled na luku i trg koji je oko te luke što je najljepši dio moje kuće koja nam je prodana (perche mi priva dela prospetiva del porto e dela piaza ch atorno el ditto porto ch e la miglior parte de casa mia a noi venduta) ugovorom u Veneciji po kojem je slobodna sa svih strana i sa svim svojim komoditetom prije više od 30 godina... te stoga želim uživati u pogledu na isti način kao što to on želi, pa vas molim da to potvrdite šaljući dvije osobe koje bi provjerile liniju zapadnog ugla njegove gradnje usporedivši je s pogledom $s$ mog prozora.... $\mathbb{1}^{22}$

Dalje navodi da je takva kuća za njega jedva upotrebljiva: »Ako se ta gradnja nastavi, što je po sudu rođaka i meštara gosp. Franje neophodno, morat će napustiti svoju kuću i ostaviti je nenastanjenom jer kao što kažu liječnici fetor et dolor interimunt homines et sunt de sume prosternentibus virtutem, što se nije stvar koju se može trpjeti... «13 Čini se da je Petar Hektorović kuću zaista i napustio poslije presude koja nije njemu išla u korist. Naime, 1567. godine iznajmljuje vrt kod crkve Svih svetih, dakle ispod svoje kuće na zidinama, Tomi Markoviću iz Krajine, što je doista posve drukčije ponašanje u odnosu na njegova oca koji na istom prostoru podiže odrine. Dokument o najmu sastavljen je u Starom Gradu, »Phari in Ciuitate Veteri in Domo habitationis sp: D. Petri Hectorei... «, a isto tako je Marković dužan donositi najam u Stari Grad, »... in domo eius habitationis dumodo sit in districtu Phariae...«, što bjelodano pokazuje posve tanke veze Petra Hektorovića s Hvarom na kraju njegova života. ${ }^{24}$

Dokumenti spora između Petra Hektorovića i Frane Paladinića iz 1524. i 1525. godine donose brojne opise sklopa Paladinića na hvarskoj Pjaci, koji veličinom daleko nadmašuje slične gradnje kasnog 15 . i početaka 16 . stoljeća na prostoru komune. Petar Hektorović je u pismu od 28. listopada 1524. godine ukratko opisao sklop ljetne i zimske palače Paladinić: »Gospodin Franjo, imajući stojnu kuću u gradu Hvaru iznad gradskih zidina, ispred koje je izvan grada druga njegova kuća ili bastion, velika i prostrana da može primiti dvije tisuće ljudi (!!!), sa ograđenim dvorištem koje se nalazi između spomenute kuće izvana i one nad gradskim zidinama unutar grada; i probivši već ranije vrata iz svoje kuće kroz gradski zid da bi po svojoj volji mogao izlaziti iz grada, gospoda suci su mu naložili da zazida vrata u zidinama, (...) jer nijedna privatna osoba nema prava slobodnog ulaza i izlaza iz grada...« Zanimljivo je da Hektorović donju ili ljetnu palaču Paladinić naziva bastionom, na osnovi čega bi se moglo pretpostaviti da je gradnja palače izvan zidina, a u posrednoj blizini glavnih gradskih zidina imala svoju "pretpovijest « u obliku, ili barem nazivanjem, nekakve fortifikacije ili fortificiranog izbačaja uz južni potez zidina koji je pojačavao obranu glavnih gradskih vrata.

Prigradnju - predmet spora - Hektorović u istom pismu opisuje sljedećim riječima:»Prošlog kolovoza, bez obziranja prema Vašoj Visosti i bez razmišljanja o šteti i inkomodiranju susjeda, gospodin Frano je na tom mjestu započeo gradnju jednog jadnog zida koji neki zovu toreta (kulica), neki potrebica, netko ovako netko onako, na gradskim zidinama pod kućom nekad Gazarovića ili Piretića, koja je nedavno pripala gosp. Franji po ispravi na koju sam na vrijeme upozorio i žalio se, i to pred mojom kućom sa velikim štetama i beskrajnim dekomodiranjem, te sramotom za moju kuću... $\aleph^{25}$

Paladinić uskoro odgovara Hektoroviću gdje ukratko opisuje svoj sklop: »... ja Franjo Paladinić s gosp. Tomom Griphico odgovaram i velim da imam kuću nad gradskim zidinama i drugu ispred nje zvanu na svoj način bastion $s$ dvorištem između njih, koje je zatvoreno sa svih strana, što je vrlo važna stvar za cijeli grad, i da nije moguće da privatna osoba ulazi ili izlazi. ${ }^{26}$ Paladinić naglašava da je sklop sagrađen odavno: »... i sve te gradnje su napravljene pred stotinjak godina..., i ukras su i ljepota vašeg grada što V. M. dobro vidi ...«, a slične je starosti i kuća Petra Hektorovića na zidinama za koju naglašava da je njegov predak don Pavao Paladinić sklopio 1458. godine ugovor s »pok. Ivanom Mišetićem glavnim tvorcem i vlasnikom kuće koja je sada vlasništvo gosp. Petra Hektorovića«. Prema njegovu mišljenju glavna Petrova nakana je ugrožavanje spokoja njegova vrta koji se nalazi između dviju kuća: »gdje kaže da sam zauzeo prostor izvan grada tako da ne može bacati vodu i druge stvari, treba mu odgovoriti da se svatko mora zadovoljiti sa svojim, a ne tražiti tuđe kao što bi htio gosp. Petar koji na moj vrt želi bacati vodu i smeće (sopra lorto mio butar aqua et scovace), quod neganti parti me offero probaturum, i da je zid na kojem gradim moj i zapadno od njega da je sve moje do Nikolinija, te istočno od zida do vrta gosp. Petra. (...) gradim i podizat ću stari zid koji po dozvoli i privoli njegovih prethodnika mogu dizati koliko želim prema dokumentu koji prilažem. « $^{27}$

Posebno isticanje ladanjskog elementa nalazi se u pismu Hektorovića iz 1525. godine u kojem, ne bez zavisti, ističe jedan ladanjski element na sklopu Paladinića: »Lijepo krunište sa šetnicom pred kućom su napravili njegovi stari za ugodu i da bi pokazali svoju posebnost jer nitko osim njih to nema u gradu; uživaj je, velim, i nastavi sa čestitim radovima na svome a ne sa štetom i uvredom susjeda. ${ }^{28}$ Moguće je da je riječ o balkonu na gornjoj palači, za kojeg će C. Fisković naglasiti da je to "... vrlo rijetko unošenje hortikulturnog motiva na pročelje gradske kuće što odaje istančanost osjećaja za udobnost «, a na kojem su poslije podignuti stupovi odrine što je izravan utjecaj rješenja $s$ Lucićeva suburbanog ljetnikovca. ${ }^{29}$

$\mathrm{U}$ istom pismu doznaje se glavni Paladinićev argument zbog kojeg podiže toretu. »I još se ubogo ispričava da gradi samo zaklon kako mu izvana ne bi gledali u kuću, a mogao je zazidati prozore da ga sunce ne vrijeđa i da ga drugi ne 


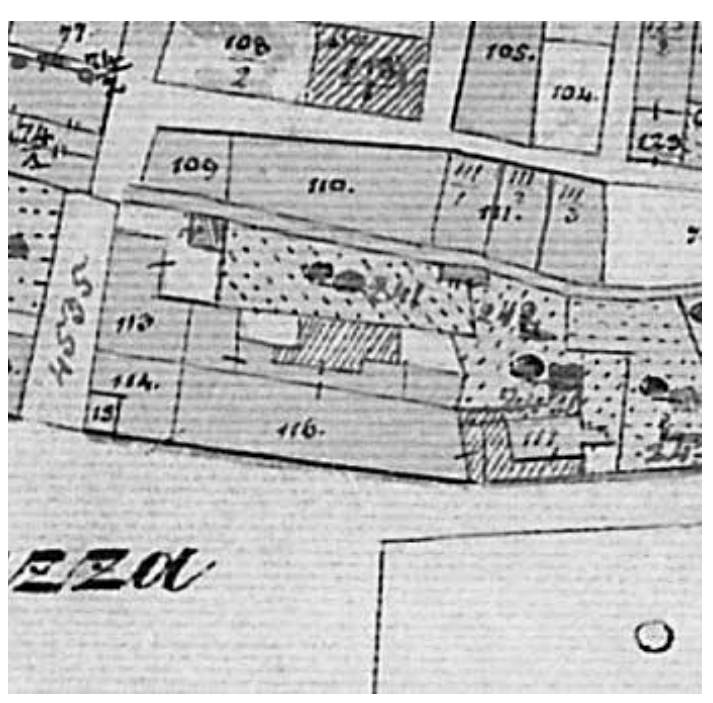

Katastarska snimka Hvara iz 1834. godine, s reambulacijom iz 1881. godine, detalj gornje i donje palače Paladinić na Pjaci / Land Registry survey plan of Hvar in 1834, with a reambulation dated 1881, detail of the upper and lower Paladinić Palace in the piazza

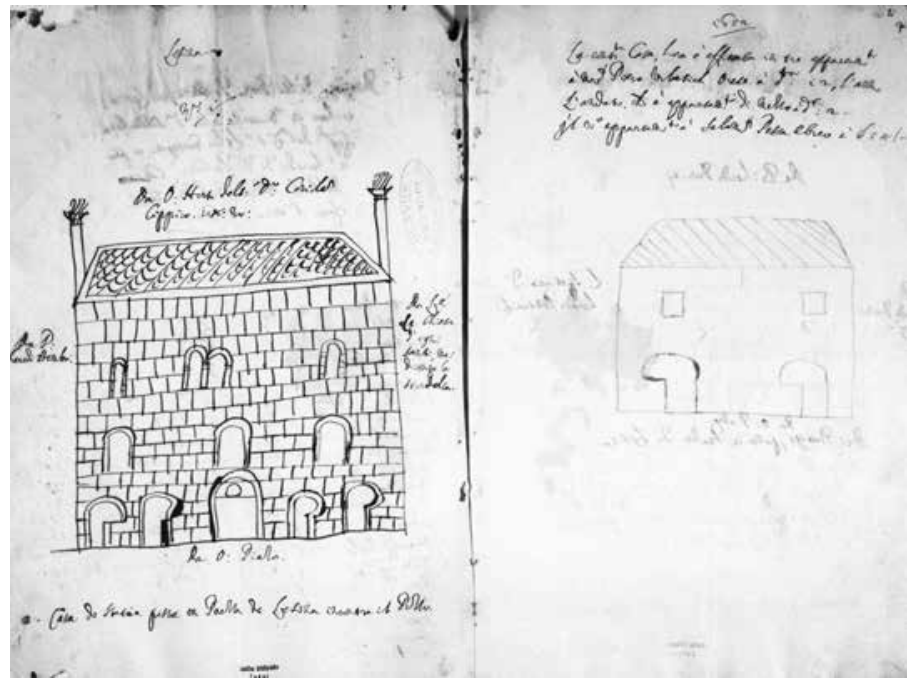

Državni arhiv u Zadru, crtež donje palače Paladinić, sredina 17. stoljeća / State Archives in Zadar, drawing of lower Paladinić palace, mid-seventeenth century

vide. $\aleph^{30}$ Dakle, da pročelja palača uz vrt i prostor samog vrta zaokruži u zatvorenu cjelinu. ${ }^{31}$

Petar Hektorović izgubio je spor protiv Frane Paladinića ili »Franciska Paladinića«, kako ga naziva Hanibal Lucić i kojem je udvorno posvetio svoju Robinju, a što je bjelodano svjedočanstvo o snazi položaja soprakomita Paladinića. ${ }^{32}$

Na samom početku 17. stoljeća u obje palače Paladinić, ljetnoj i zimskoj, bila je smještena vojna bolnica mletačke mornarice. Oskudni podaci o djelovanju ove bolnice poznate su iz hvarskih arhiva, primjerice da je plemić Jakov Lucić bio predstojnik bolnice, a da je komunalni liječnik Francesco Avosta dobivao 25 dukata mjesečno za liječenje vojnika i mornara u ovoj bolnici. Međutim, najviše podataka nalazi se u zahtjevu sestara Grisogono iz Zadra koje traže da im mletačka mornarica vrati obje kuće s vrtom između njih. Navedene sestre su baštinice Paladinića a, kako navode, vojska je 1617. godine na silu izbacila zakupnike kuća i tu uselila bolnicu. Navodi se da su u gornjoj kući smješteni liječnici i ranarnici, a u donjoj bolesnici, dok je vrt između njih, nekada s prekrasnim narančama, »bellissimi melaranci«, potpuno uništen. Tražile su da im se isplati najamnina, kao i naknada za počinjene štete. Najamninu su dobile, ali ne i obeštećenje tako da je njihova majka platila popravke. No, 1621. godine ponovno se u kuće bespravno uselila vojska. Tada su se tužile najvišim instancijama i uskoro dobile zadovoljštinu jer generalni providru F. Belegno sljedeće godine govori o hitnoj potrebi gradnje bolnice $\mathrm{u}$ Hvaru. ${ }^{33}$ Ista je sagrađena 1723. godine i do danas stoji kao jedan od najranijih namjenski građenih bolničkih objekata u Hrvatskoj.

Među dokumentima obitelji Paladinić koji se danas čuvaju u Državnom arhivu u Zadru, u fondu »Disegno delli Beni Paladini«, čuvaju se dva, posve nespretna i shemati-

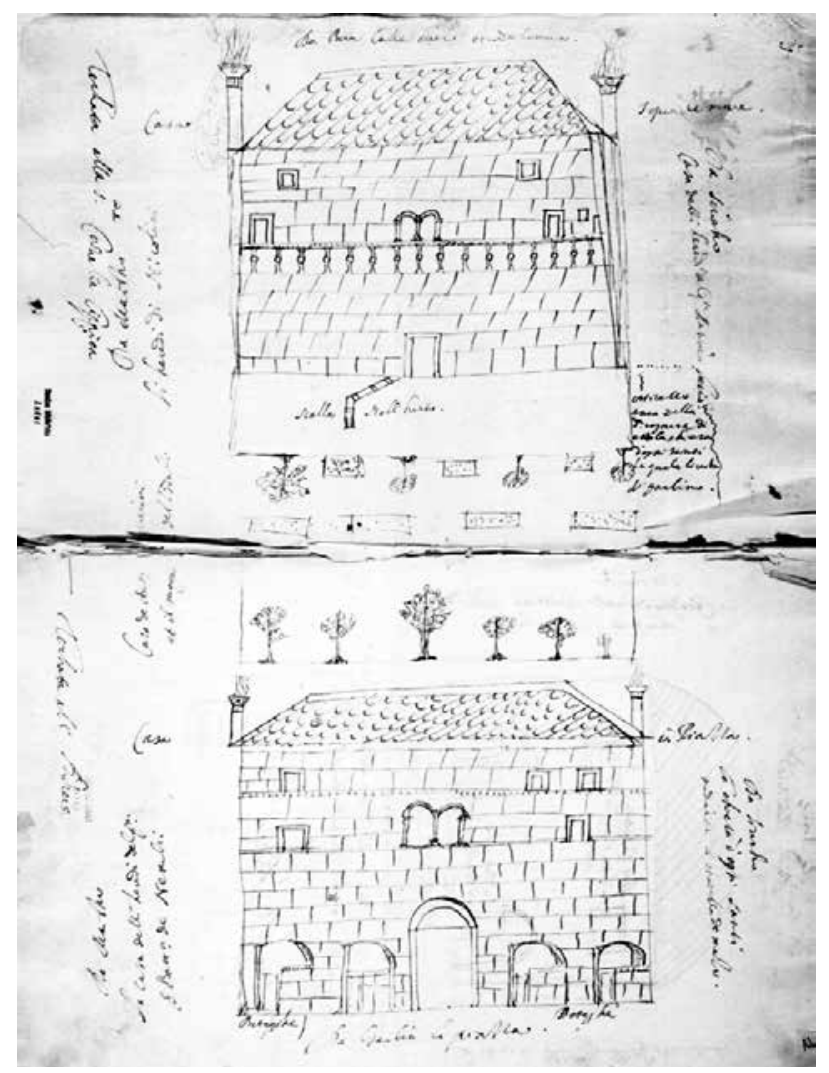

Državni arhiv u Zadru, crtež sklopa donje i gornje palače Paladinić s perivojem u sredini, sredina 17. stoljeća / State Archives in Zadar, drawing of the lower and upper Paladinic palace complex, with a park between them, mid-seventeenth century

zirana, crteža palača Paladinić na hvarskoj Pjaci. Prvi crtež prikazuje samo donju ljetnu palaču Paladinić i nosi naslov Casa di Nation posta in Piazza di Lessina incontra nob. di 


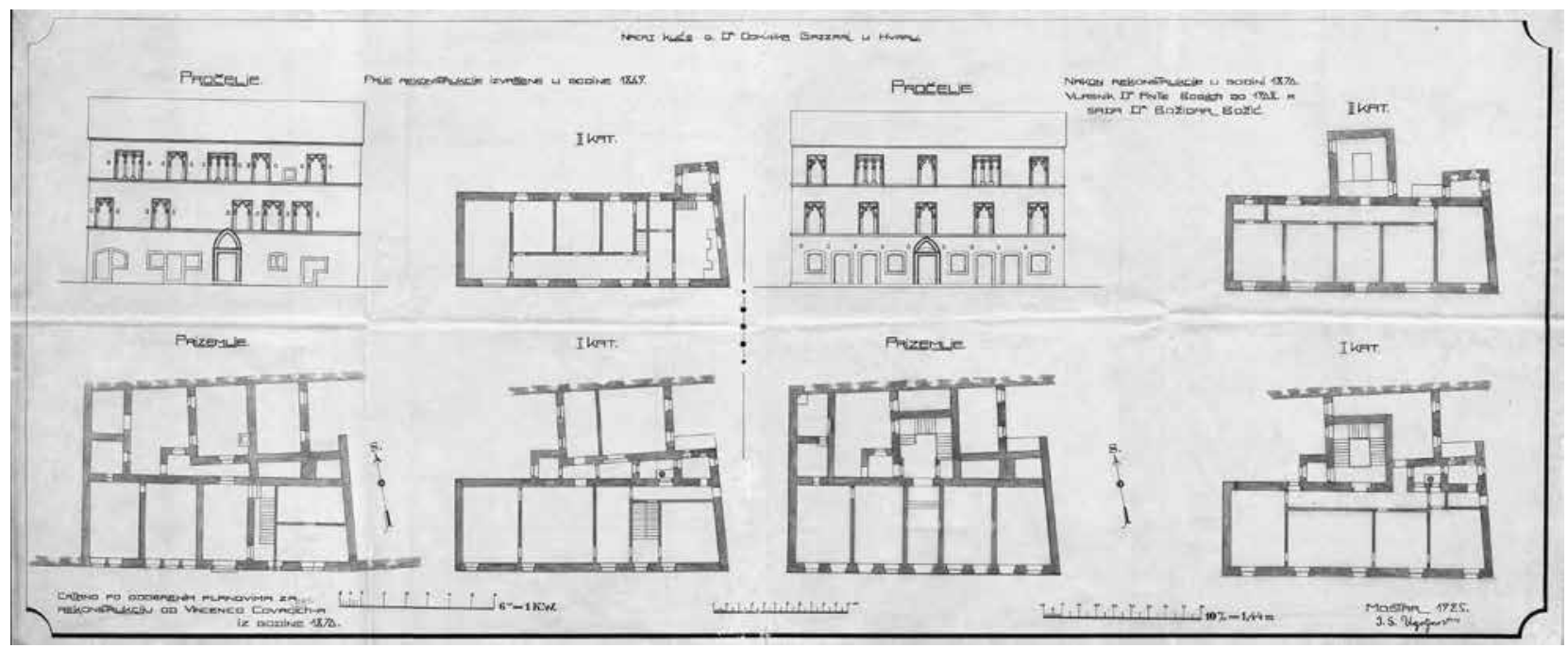

Muzej hvarske baštine, precrtani izvorni projekt rekonstrukcije donje palače Paladinić iz 1870. godine, Mostar, 1925. godine (autor: J. S. Ugoljkov) / Hvar Heritage Museum, copy of the original project of reconstruction of the lower Paladinić palace 1870, Mostar 1925 (author: J. S. Ugoljkov)

Traù il Pozzo. Drugi crtež donosi obje palače s vrtom između koji je prema crtežu ograđen zidom. Nema poseban naslov, a kuće se razlikuju po smještaju, »in Piazza«, za ljetnu palaču, i na zidinama, »sopra le mure«, za zimsku palaču Paladinić.

Nije poznat autor crteža, a nastali su sredinom 17. stoljeća kao dio fonda u kojem su ucrtane sve nekretnine obitelji Paladinić. Pored navedenih kuća u Hvaru, doneseni su crteži starigradskog i viškog ljetnikovca. Osim nespretnosti i shematiziranosti, crteži inzistiraju na otvorima s polukružnim lukovima, a u rasporedu otvora su posve pogrešni. Valja ipak istaknuti veliki balkon zimske palače Paladinić, ali bez stupova odrine. Sasvim je vjerojatno da autora crteža treba tražiti među nekim od trogirskih nasljednika, a također je sasvim moguće da je palače poznavao samo prema opisu, a da ih nikada nije vidio uživo. ${ }^{34}$

Ljetna palača Paladinić je 1716. godine bila u vlasništvu braće Zeni, a prizemlje se dijelom iznajmljivalo Riječanima, Fiumani, što je općeniti naziv, dugo u upotrebi, za trgovce drvom. Drugi je dio bio iznajmljen za ljekarnu, »Spiciaria«, a zanimljivo je napomenuti da je ljekarna na tom mjestu i danas. Godine 1780. palača je u vlasništvu obitelji Bučić, a iste je godine u prizemlju Cesare Brescio osnovao Casino, otmjeni, plemićki klub u kojem se kartalo, a česta su bila ranjavanja mačem u kartaškim svađama. Brescio je 1795. godine dodatno uložio u ovaj prostor te je otvorio kavanu, "Bottega di Caffè«, a držao ju je barem do 1816. godine. $\mathrm{Na}$ istom je mjestu kavanu držala Antica Marchi od 1836. do 1855. godine. Povijest ovog Casina i kavane nije detaljnije poznata, ali je ukinuta tek 1870. godine, iste godine u kojoj Domenico Gazzari dobiva dozvolu za stanovanje u obnovljenoj palači. Iste godine palača je iznajmljena za sjedište Kotarskog poglavarstva, a već ranije D. Gazzari iznajmljuje dio kata za c. k. okružnog povjerenika. Prilikom posjeta cara Frane Josipa 1875. u palači je bila njegova službena rezidencija.

Važan izvor za poznavanje prostorne organizacije palače Paladinić su i planovi iz prve polovine 19. stoljeća. Plan grada Hvara koji je izradila austrijska vojska 1825. godine shematski pokazuje tlocrt donje palače Paladinić i njezin odnos prema drevnoj crkvi Svih svetih koja se nalazila $\mathrm{s}$ njezine istočne strane kao samostalna građevina okružena dvorištem i vrtom. ${ }^{35}$ Prema ovom izvoru palača je imala U-tlocrt, a perivoj se protezao sve do sjevernoga, začelnog zida palače.

Desetak godina poslije, 1834., napravljena je službena katastarska snimka grada na kojoj je tlocrt palače ucrtan znatno preciznije. ${ }^{36}$ Oblika je izduženog pravokutnika položenog paralelno sa smjerom pružanja trga na kojem je smještena. U začelju su na osnovni volumen dograđena tri volumena, a između njih i perivoja nalazi se manje dvorište. Zapadna dogradnja postavljena je okomito, uz sami rub začelnog pročelja, a pruža se do perivoja te zatvara dvorište sa zapadne strane. Tlocrt središnje dogradnje je oblika pravilnog ali plitkog U-tlocrta. $\mathrm{Na}$ istočnom rubu začelja palače dograđen je volumen kvadratičnog tlocrta, kojeg je Petar Hektorović nazivao kulom i zbog kojeg se 1524. i 1525. svađao s Franom Paladinićem i zbog koje se, povrijeđen zbog presude u korist Paladinića, trajno preselio u svoj ljetnikovac u Starom Gradu.

Crkva Svih svetih prikazana je s kvadratnom apsidom, položena u pravcu istok - zapad. Ispred njezina glavnoga, zapadnog te bočnoga, južnog pročelja okrenutog prema Pjaci nalazi se ograđeno dvorište. Uz ostala pročelja, sve do gradskog zida nalazi se prostrani vrt, koji još 1458 . 


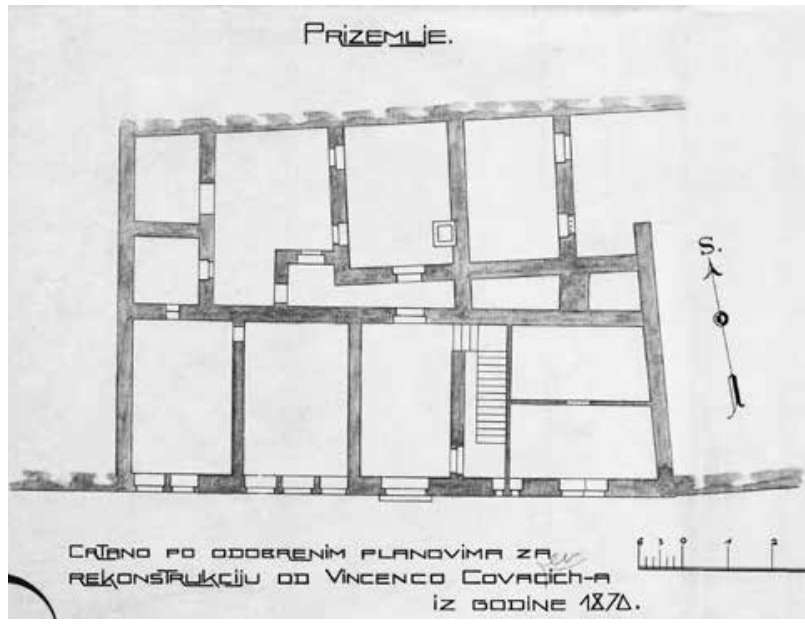

Muzej hvarske baštine, precrtani izvorni projekt rekonstrukcije donje palače Paladinić iz 1870. godine, Mostar, 1925. godine, detalj izvornog stanja prizemlja (autor: J. S. Ugoljkov) / Hvar Heritage Museum, copy of the original project of reconstruction of the lower Paladinić palace 1870, Mostar 1925, detail of the original state of the ground floor (author: J. S. Ugoljkov)

godine spominje arhiđakon Pavle Paladinić u prevažnom dokumentu koji je de facto odredio perimetar budućega glavnog gradskog trga.

Spomenuta katastarska snimka donosi i reambulaciju iz 1881. godine koja je prikazana kao crvena šrafura, a njome su zabilježeni svi zahvati između 1834. i 1881. godine. U tom je razdoblju napravljena prigradnja na središnjem dijelu začelnog pročelja čime je nekadašnje dvorište svedeno na male ulomke na istočnom i zapadnom rubu. Ovdje je zabilježen zahvat koji se dogodio prije zahvata D. Gazzarija 1869. godine. Naime, usporedbom nacrta stanja prije zahvata iz 1869. godine s onim što je te godine napravljeno može se zaključiti da su svi zahvati odrađeni u okvirima već postojećeg tlocrta kuće, dakle bez prigradnji u začelju. Reambulacija dakle bilježi nepoznati zahvat koji se dogodio između 1834. i 1869. godine. U katastarskom izvatku za broj 116 , što je čestica zgrade ljetne palače Paladinić, stoji sljedeći opis: Casa d' abbitazione a 3 piani d' un terazze d' un corte. Opis nije križan ili prepravljan što znači da je nastao 1834. godine. Zanimljiv je, naravno, zbog spomena terase kojoj se danas ne vide tragovi. Može se pretpostaviti da je postojala uz začelje kuće, te da je nestala spomenutom prigradnjom između 1834. i 1869. godine.

Domenico Gazzari je 1854. godine kupio susjednu crkvicu Svih svetih i dao je porušiti. ${ }^{37}$ Na njezinu mjestu je od 1858. do 1859. godine sagradio jednokatnicu koja je 1888. povišena za kat, a što je također zabilježeno na reambulaciji katastarske snimke iz 1881. godine. Prvi nacrt izradio je Vicko Kovačević, međutim izvedena kuća ne odgovara izvornom nacrtu te je za pretpostaviti da je sagrađena prema nacrtima Nikole Marchija koji je projektirao i njezino povišenje 1888. godine. ${ }^{38}$ Dakle, 1888. godine pokriveno je

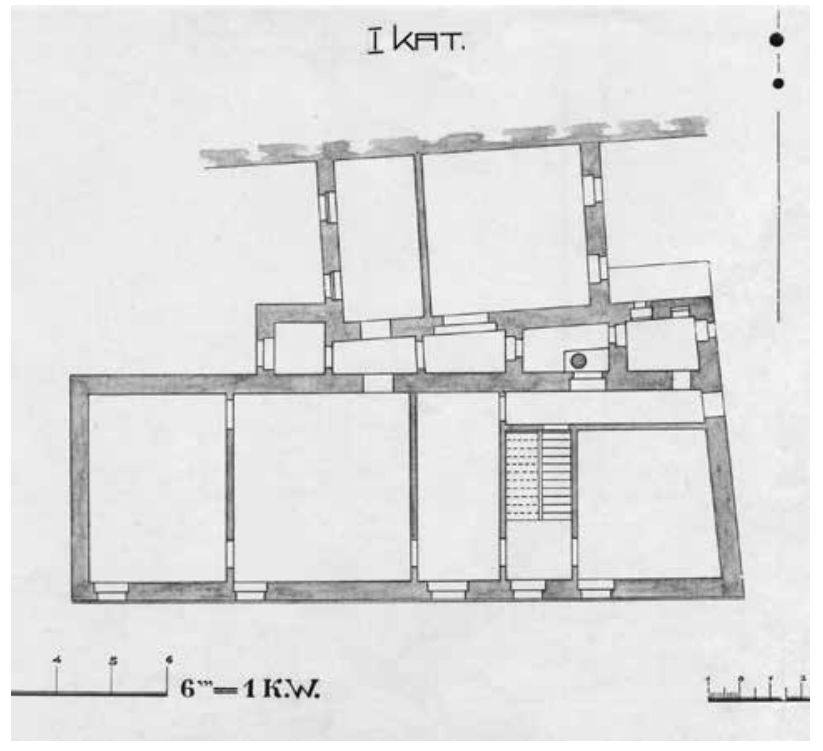

Muzej hvarske baštine, precrtani izvorni projekt rekonstrukcije donje palače Paladinić iz 1870. godine, Mostar, 1925. godine, detalj izvornog stanja prvog kata (autor: J. S. Ugoljkov) / Hvar Heritage Museum, copy of the original project of reconstruction of the lower Paladinić palace 1870, Mostar 1925, detail of the original state of the first floor (author: J. S. Ugoljkov)

u cijelosti, nekada posve otvoreno, istočno pročelje ljetne palače Paladinić. O njegovoj izvornoj raščlambi ili arhitektonskom ukrasu nema sačuvanih vijesti.

Velika preinaka ljetne palače Paladinić na hvarskoj Pjaci izvedena je od 1868. do travnja 1869. godine. Naručitelj je bio njezin tadašnji vlasnik dr. Domenico Gazzari, zagriženi vođa autonomaša na otoku Hvaru što je bilo, kako će se vidjeti, od glavnog značenja prilikom preoblikovanja palače. Tada je palača nosila gradski broj 40 bez imena trga ili ulice. Radove je vodio splitski majstor Grgur Grle, dok je projektant preinake najvjerojatnije Hvaranin Vicko Kovačević.

Nacrt koji se čuva u arhivu Muzeja hvarske baštine u Hvaru nosi naslov Nacrt kuće g. Dr. Dominika Gazzari u Hvaru. ${ }^{39}$ Opremljen je brojnim legendama, pisanim lijepim secesijskim rukopisom, na osnovi kojih doznajemo osnovne podatke o njegovu nastanku. Nastao je u Mostaru 1925. godine, gdje je tada kao ugledan odvjetnik živio Božidar Božić koji je 1909. godine naslijedio palaču. ${ }^{40}$

Riječ je o precrtu izvornog nacrta Vicka Kovačevića iz 1870. godine, kako je navedeno: „Crtano po odobrenim planovima za rekonstrukciju od Vincenco Kovacich-a«. Ovdje je krivo doneseno ime projektanta, čije je prezime Kovačević poznato iz brojnih nacrta druge polovine 19. stoljeća. Precrt je izradio J. S. Ugoljkov.

Tlocrti katova i nacrt glavnoga, južnog pročelja podijeljeni su u dva dijela. Prvi dio nosi naslov Prije rekonstrukcije izvršene u godini 1869., dok je drugi naslovljen Nakon rekonstrukcije u godini 1870. Vlasnik Dr. Ante Boglich do 1908. a sada Dr. Božidar Božić. 


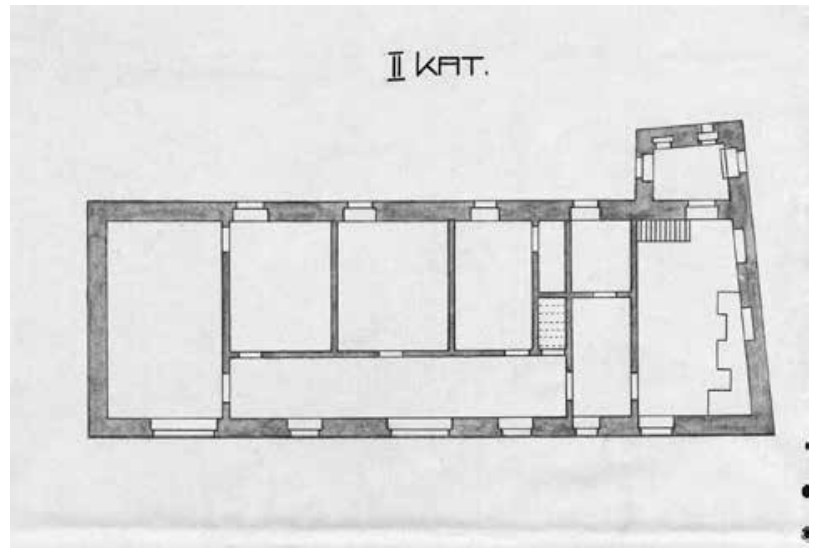

Muzej hvarske baštine, precrtani izvorni projekt rekonstrukcije donje palače Paladinić iz 1870. godine, Mostar, 1925. godine, detalj izvornog stanja drugog kata (autor: J. S. Ugoljkov) / Hvar Heritage Museum, copy of the original project of reconstruction of the lower Paladinić palace 1870, Mostar 1925, detail of the original state of the second floor (author: J. S. Ugoljkov)

Posebno je važna činjenica da su zahvati iz 1868. i 1869. godine istaknuti crvenom bojom, čime se jasno razlikuju od stanja naslijeđenog iz prethodnog razdoblja.

Kako je vidljivo na katastarskoj snimci iz 1834. godine, prizemlje palače se sastoji od pravilnoga, pravokutnog tlocrta glavnog volumena palače te raznih prigradnji u njezinu zaleđu. Jasan U-tlocrt zabilježen na planu grada iz 1825. godine na ovom tlocrtu više nije vidljiv iako je jasno da posve čisti, planirani U-tlocrt u začelju na ovoj palači nije ni postojao, odnosno da je prikaz na planu iz 1825. godine znatno shematiziran.

Bitno je uočiti da povezanost ljetne i zimske palače Paladinić više ne postoji iako se iz prostorne organizacije jedne i druge palače može iščitati. Sredinom 19. stoljeća Paladinići su izumrli već gotovo četiri stoljeća, a njihove su kuće promijenile broje vlasnike. Ljetna, donja palača zidom je odvojena od dvorišta gornje palače, također više ne postoji ni dvorište u začelju ljetne palače, koje se može iščitati iz katastarske snimke iz 1834. godine. Ono je, prema ovom tlocrtu, sačuvano samo u detalju na sjeveroistočnom dijelu i povezano s dvorištem kuće s istoka jer je i ta kuća, kako je prije navedeno, od 1854. godine vlasništvo Domenica Gazzarija.

Prizemlje glavnog volumena palače podijeljeno je na pet dijelova nejednake veličine koji se pružaju cijelom širinom prizemlja. Iznimka je prostor na istočnom rubu koji je tankom pregradom, muniginom, podijeljen na prednji i stražnji dio. Dva prostora na zapadnom dijelu, te spomenuti, podijeljeni prostor na istočnom rubu namijenjeni su dućanima, odnosno casinu i kavani kako je prije spomenuto. Zanimljiv je komunikacijski blok u središnjem dijelu prizemlja. Veliki, gotički portal u središnjoj osi vodi u introit, predvorje kojim je vanjski prostor trga povezan sa stubištem kao vertikalnom komunikacijom, a vratima na sjevernom zidu s volumenima

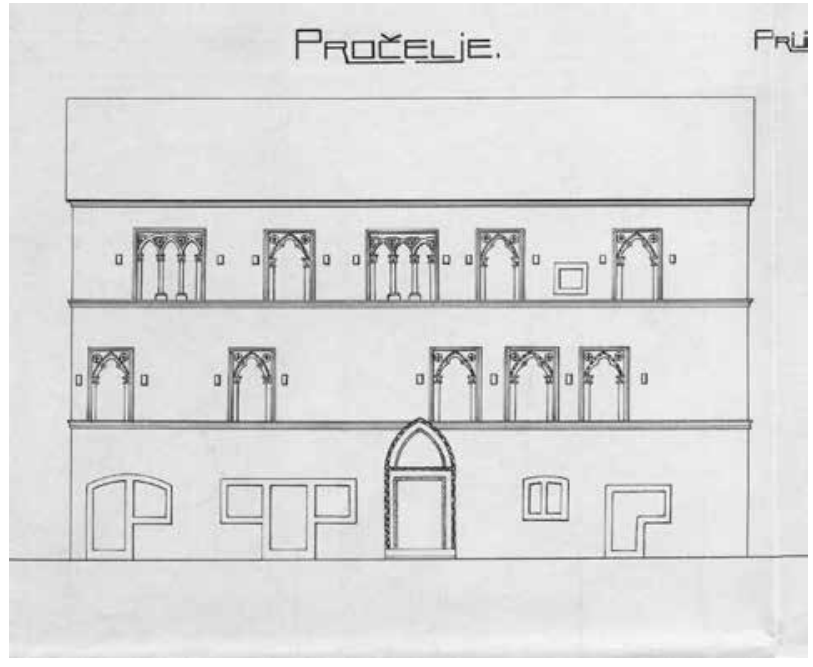

Muzej hvarske baštine, precrtani izvorni projekt rekonstrukcije donje palače Paladinić iz 1870. godine, Mostar, 1925. godine, detalj izvornog stanja glavnog pročelja (autor: J. S. Ugoljkov) / Hvar Heritage Museum, copy of the original project of reconstruction of the lower Paladinić palace 1870, Mostar 1925, detail of the original state of the palace front (author: J. S. Ugoljkov)

dogradnji uz začelni zid palače. Stubište se kao zasebni volumen nalazi odmah uz istočni zid predvorja. U prizemlju je to usko, jednokrako stubište.

Dogradnje uz začelje palače ne pokazuju jasnu prostornu organizaciju; riječ je o funkcionalnim adicijama, danas većinom nepoznate namjene, koje su kroz vrijeme podizane uz začelje. Jedino je uz zapadni zid kule na sjeveroistočnom zidu podignuta cisterna što je vidljivo iz činjenice da ne postoji nijedan otvor na njezinim zidovima, a da je na katu ucrtana kruna cisterne. Posve je zazidano i prizemlje spomenute prigradnje uz sjeveroistočni ugao, one koju P. Hektorović naziva kulom. Međutim, namjena ovog prizemlja nije jasna, a moguće je pretpostaviti da je zatvoreno iz fortifikacijskih razloga iako je njezina stvarna obrambena uloga posve izlišna.

Vrijedno je napomenuti da se u jednoj prostoriji na središnjem dijelu ovih prigradnji nalazi kruna bunara, a moguće je da je nekada stajala slobodno u otvorenom, renesansnom dvorištu. Ova kruna nije sačuvana.

Najveća razlika između prvog kata i prizemlja ljetne palače Paladinić je u činjenici da se nijedan široki zid, kojima je prizemlje organizirano, ne prenosi na kat. Ondje su samo vanjski zidovi široki, dok je unutrašnja organizacija postignuta tankim, pregradnim zidovima.

Unutrašnji prostor kata podijeljen je na dvije velike sobe na zapadnoj polovici, dok se na istočnoj polovici javlja jedna manja soba koja veličinom i smještajem prati prostor predvorja, potom se nastavlja prostor namijenjen stubištu koji je veći od sličnog prostora u prizemlju i gdje se javlja dvokrako stubište. Na istočnom rubu postavljena je manja soba koja ne zahvaća cijelu širinu kata, a u njezinu zaleđu javlja 
se hodnik koji je povezan s dogradnjama u začelju palače. Sudeći po vezi s prostorijom u kojoj se nalazi kruna cisterne, potom vezama s ostalim prostorijama, ovaj je hodnik bio namijenjen posluzi i služio je vezi kuhinje s prostorijama na katu. Također se može pretpostaviti da je ovdje bio smješten piano nobile, salon s drugim zajedničkim prostorijama. Važno je uočiti da su vrata na južnom dijelu prostorija kata postavljena u jedan red, enfiladu, dakle cijeli se kat mogao povezati u funkcionalnu cjelinu otvaranjem ovih vrata. Ovo je međutim barokna karakteristika organizacije prostora te upućuje na zaključak da je i prije druge polovine 19. stoljeća palača doživljavala preinake unutrašnjosti. Prema povijesnim podacima, moguće je da se to dogodilo poslije devastacije unutrašnjosti kuće za njezina bespravnog korištena kao vojne bolnice na početku 17. stoljeća.

Prostorna organizacija drugog kata postignuta je također tankim pregradnim zidovima. Od prigradnji uz začelje palače do visine drugog kata diže se jedino prigradnja kule koja je toliko mučila Petra Hektorovića da ga je, kako se čini, trajno potjerala iz grada na ladanje.

Dakle, čitanjem tlocrta pojedinih etaža može se utvrditi da su prigradnje uz zapadni dio začelja palače bile visine prizemlja, da su prigradnje uz središnji dio bile visine kata, a da je punu visinu palače pratila samo prigradnja spomenute, torette ili castela, kako je nazivaju spisi parnice Frane Paladinića i Petra Hektorovića.

Raspored prostorija drugog kata pokazuje razlog zbog kojeg je ova palača nosila naziv ljetna. Na zapadnom i središnjem dijelu kata nalaze se četiri prostorije: na zapadnom rubu smještena je soba koja zahvaća cijelu širinu kata, no na središnjem dijelu kata nalaze se tri sobe smještene uz začelje, dok je uz glavno pročelje smješten hodnik. Dakle, spavaće sobe postavljene su u sjenu začelja, a iza bogato raščlanjenog pročelja nalazi se samo hodnik.

$\mathrm{Na}$ istočnom rubu kata nalazi se nekoliko manjih prostorija, a stubište vodi u hodnik ispred glavnog pročelja. U prostoriji koja se nalazi na samom istočnom rubu nalazi se stubište koje vodi u potkrovlje.

Najvrjedniji doprinos ovog nacrta je snimka postojećeg stanja glavnog pročelja prije simetriziranja provedenog 1868. i 1869. godine. Tri su etaže na pročelju odvojene naglašenim, profiliranim markapjanom. Prizemlje i kat su podjednake veličine, dok je drugi kat nešto niži. Profilirani vijenac nalazi se i u samom zaključku pročelja.

Otvori prizemlja prava su mala zbirka dućanskih otvora. $\mathrm{Na}$ zapadnom rubu nalazi se dućanski otvor na koljeno kojem su vrata odvojena od prozora, a otvor je zaključen plitkim lukom. Do njega su dućanska vrata koja imaju dva odvojena prozora za svake strane, jednake veličine, oblikovanja i smještaja, a cjelina je zaključena ravnim nadvratnikom. U središnjoj osi prizemlja nalazi se veliki gotički portal, jedini sačuvani u gradu Hvaru. Prilikom zahvata 1868. i 1869. godine doživio je nepotrebnu devastaciju. Naime, izvorni luk bio je izduženi, elegantni gotički luk proporcionalan donjem dijelu vrata. Njegova je visina iziskivala probijanje razdjelnog vijenca prvog kata. Vrh luka prelazio je visinu prizemlja što graditeljima izvorne palače nije smetalo. Međutim, simetriziranje pročelnih otvora podrazumijevalo je postavljanje prozora u središnjoj osi prvog kata i zbog toga je luk trebalo skratiti, što je i učinjeno, a posljedica je da umjesto kasnogotičke elegantne izduženosti ovaj luk ima obris zdepastog, gotovo polukružnog luka.

Između središnjeg portala i dućanskih vrata na istočnom rubu prizemlja nalazi se manji prozor koji je, sudeći prema tlocrtu prizemlja, imao funkciju svjetlarnika stubišta i dućanskog prostora uz stubište.

Na samom istočnom rubu prizemlja nalaze se dućanska vrata na koljeno kod kojih su vrata i prozor povezani, a zaključena su ravnim nadvratnikom. Različitost oblikovanja pojedinih dućanskih vrata, kao i pojava manjeg prozora na istočnoj polovici prizemlja pokazuju da je raščlamba pročelja prizemlja nastajala postupno i sukladno potrebama pojedinog vremena.

Kat je raščlanjen s pet gotičkih monofora pri čemu su tri monofore gusto okupljene na istočnoj polovici pročelja dok su dvije postavljene na zapadnoj polovici pročelja. Njihov položaj uvjetovan je rasporedom prostorija u unutrašnjosti. Drugi je kat raščlanjen dvjema triforama i trima monoforama. Trifore su postavljene na zapadnom rubu i u središnjoj osi. Jedna je monofora simetrično postavljena između njih, dok su dvije monofore otvorene na istočnoj polovici pročelja. Između tih monofora otvoren je manji, kvadratni prozor, očito kao naknadna intervencija uzrokovana promjenom razmještaja prostorija u unutrašnjosti.

Uz svaki gotički otvor prvog i drugog kata bio je postavljen par prozorskih uha, simetrično postavljenih, njih ukupno osamnaest.

Najveće promjene ljetna palača Paladinić doživjela je u unutrašnjem rasporedu prostorija kao i u smještaju i organizaciji komunikacija u unutrašnjosti, dakle u ukupnoj unutrašnjoj prostornoj organizaciji. Unutrašnja organizacija prizemlja je potpuno izmijenjena. Središnji gotički portal vodi u predvorje koje izravno vodi do volumena višekrakog stubišta, a čiji je tlocrt zauzeo najveći dio središnjeg dijela dogradnji uz začelje palače. Dućani u prizemlju su simetrično podijeljeni na po dva sa svake strane, podjednake veličine i jednakih pročelnih otvora.

Na katu su formirane četiri sobe, postavljene uz glavno pročelje, a njima se pristupa preko hodnika koji je formiran uz začelni zid kuće. Na prvom su katu dogradnje u začelju dijelom preinačene u nusprostorije.

Drugi kat je jednako riješen kao i prvi, s tom razlikom što je na drugom katu pet soba. Također su sve orijentirane prema jugu, a u njihovu je začelju hodnik koji ih sve povezuje sa stubištem. Od pregradnih zidova u unutrašnjosti sačuvana su samo dva zida na prvom katu, a svi ostali zidovi su 


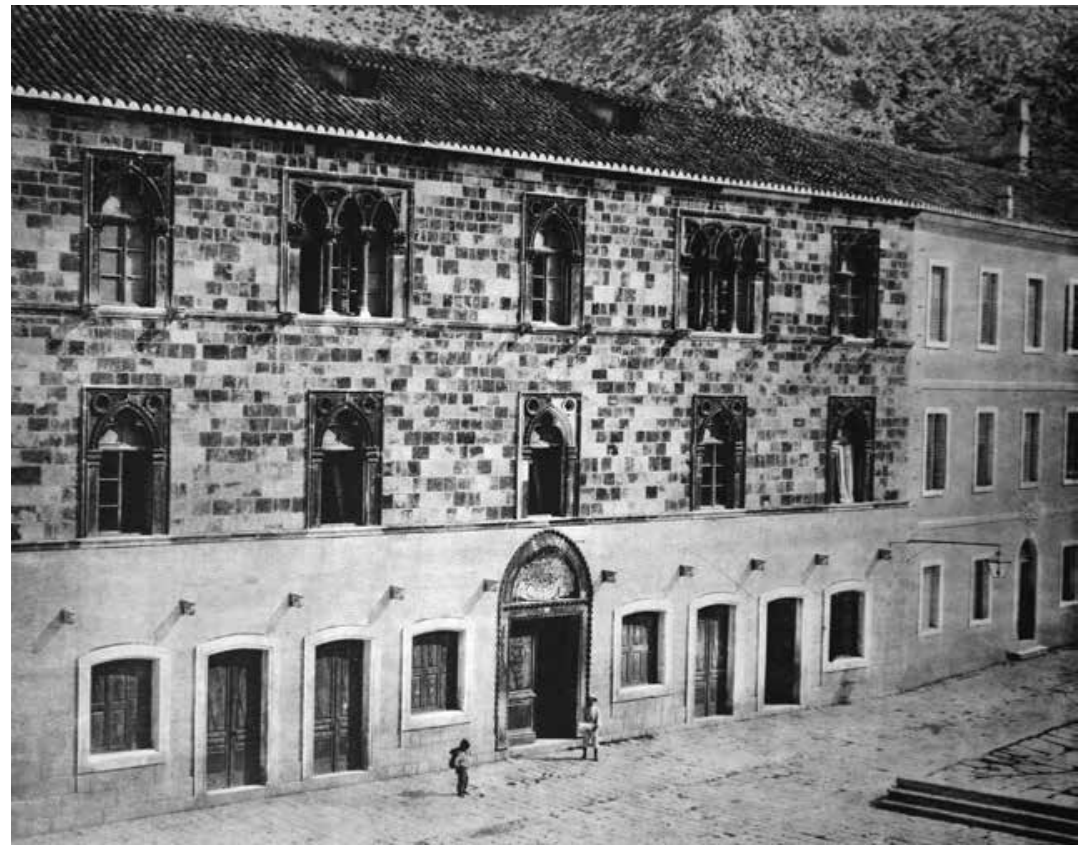

Donja palača Paladinić početkom 20. stoljeća, iz knjige CIRILLO M. IVEKOVIĆ, Dalmatiens Architektur und Plastik, Bd. VI.-VIII., Wien, 1910., 291/2 / The lower Paladinić palace at the beginning of the 20th century, from the book Dalmatiens Architektur und Plastik by CIRILLO M. IVEKOVIĆ, Vol. VI-VIII, Wien, 1910, 291/2

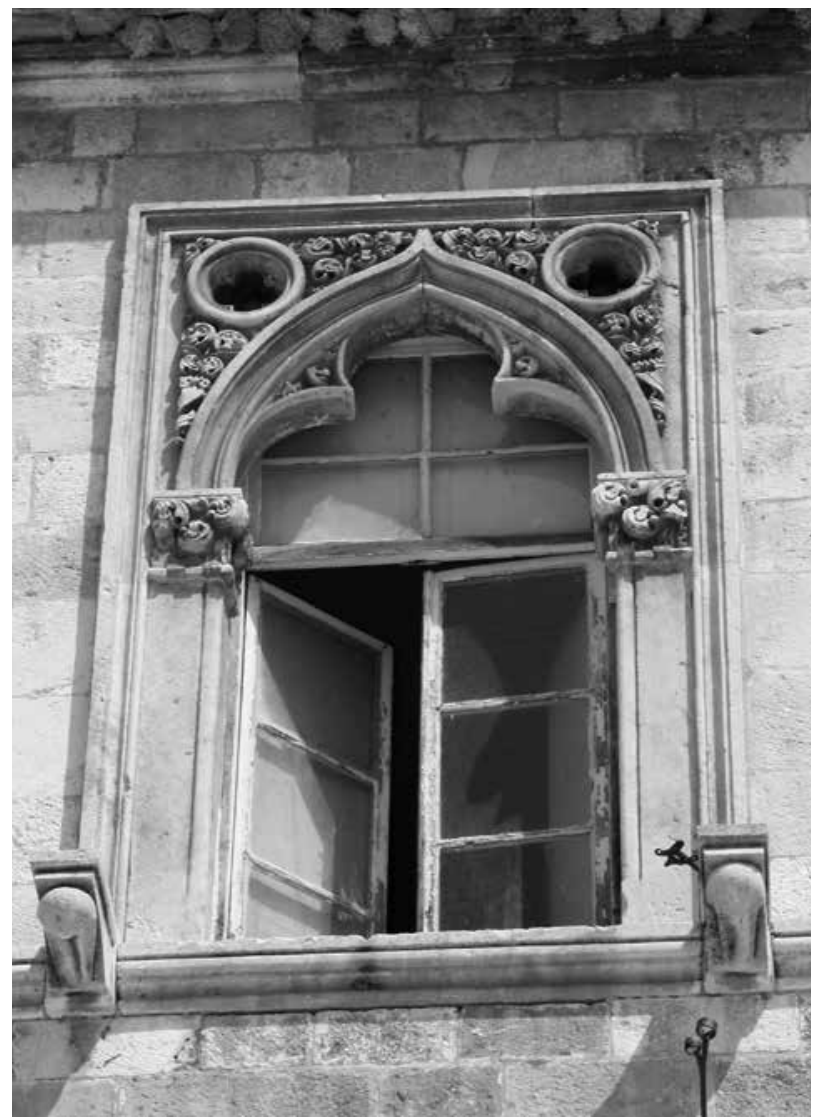

Današnje stanje donje palače Paladinić, monofora drugog kata / Present condition of the lower Paladinić palace, one-light window on the second floor posve novi. Zanimljivo je da je sačuvana i enfilada na prvom katu.

Južno, glavno pročelje doživjelo je potpunu preinaku. Već je spomenuta devastacija gotičkog portala. Umjesto prijašnjih dućanskih otvora učinjena je nova raščlamba kojom je zidno platno potpuno simetrično raščlanjeno dvojim vratima u središnjim osima istočne i zapadne strane prizemlja, a njima sa strana su otvorena po dva prozora. U osima zidnog platna između otvora su neposredno iznad otvora uzidana prozorska uha, njih ukupno deset. Iako vješt rad, sudeći prema izostanku patine, sva prozorska uha su rad iz vremena preinake palače.

Kat je raščlanjen s pet gotičkih monofora, besprijekorno simetrično postavljenih, a na pročelju drugog kata su zadržane dvije trifore i tri monofore. No potrebe striktne simetrizacije postavile su jednu monoforu u središnju os, po jednu na sam rub pročelja, dok su trifore smještene između njih. Prozori drugog kata dobili su gotičke konzole s ukrasom mesnatog lista na mjestu spoja doprozornika s razdjelnim vijencem. No ove konzole nisu preinaka nego potpuno novi element: one nisu postojale na izvornom pročelju.

Lijep dokument o zahvatu iz 1868. i 1869. godine je Ivekovićeva fotografija novog pročelja publicirana 1910. godine. ${ }^{41} \mathrm{Na}$ njoj se lijepo vidi da je prizemlje napravljeno u cijelosti od potpuno novog kamena, a da je na svome mjestu ostao samo portal, osakaćena luka. Većina kamenih kvadera na pročeljima katova je također zamijenjena. Monofora u središnjoj osi prvog kata ima promijenjenu desnu stranu luka, a svi otvori kata imaju novonapravljeni ulomak

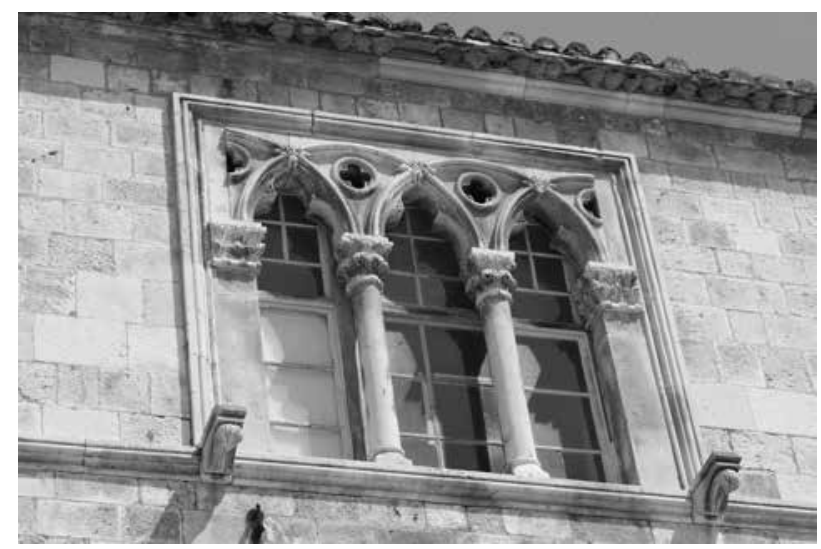

Današnje stanje donje palače Paladinić, trifora drugog kata / Present condition of the lower Paladinić palace, three-light window on the second floor 


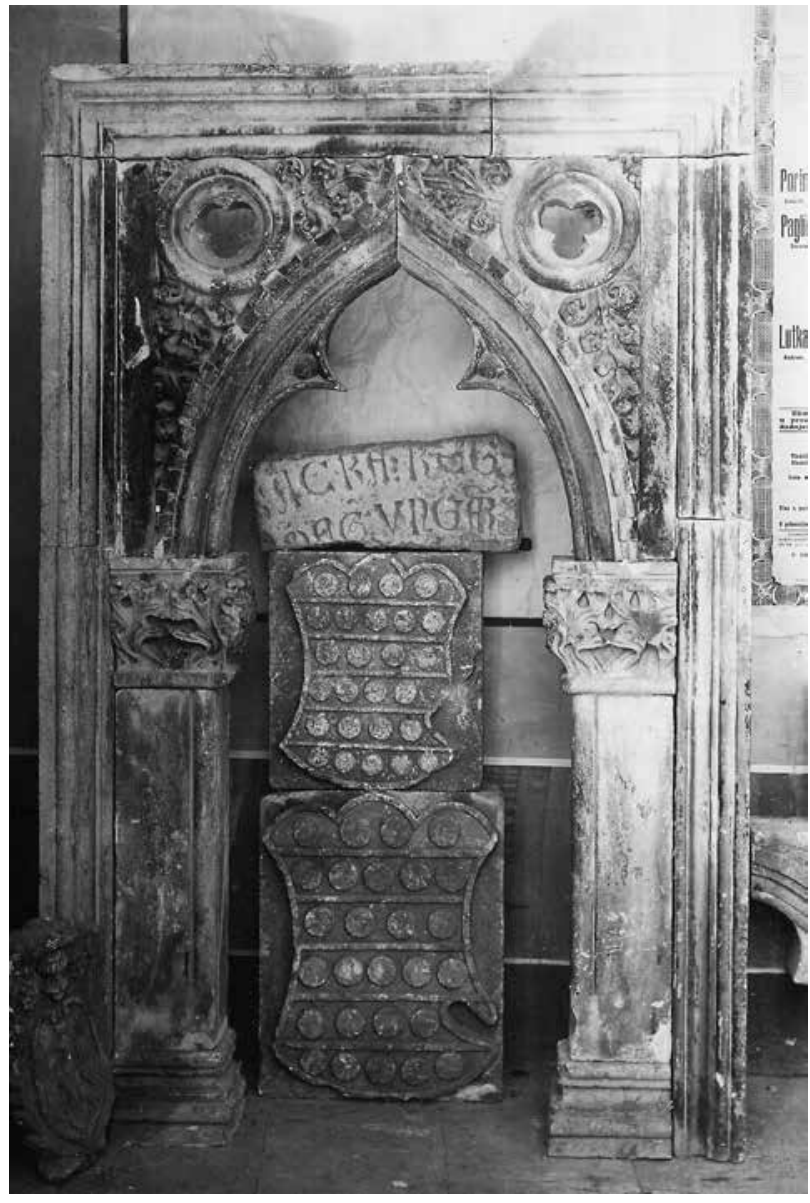

Gradski lapidarij u Korčuli, razdoblje između dva svjetska rata, kasnogotička monofora / Municipal lapidarium in Korčula, period between the Two World Wars, Late Gothic one-light window

razdjelnog vijenca u širini otvora. Krov je također evidentno novopromijenjen.

Poznato je da je novo južno pročelje palače sagrađeno 4,5 mletačkih palaca ispred pravca pružanja starog pročelja zbog slabih temelja. ${ }^{42}$ Slijeganje temelja i oštećenja koja su time nastala zasigurno su bila osnovni razlog zbog kojeg je Gazzari ušao u gradnju gotovo nove palače koja tek malo sliči na staru. Količina zamijenjenih kamenih kvadera, te ulomaka arhitektonske dekoracije čitliivih s Ivekovićeve fotografije potvrđuje obujam oštećenja izvornog pročelja.

Kompozicija glavnoga, južnog pročelja pokazuje jasnu diferencijaciju prvog od drugog kata. Na prvom katu su postavljene samo monofore jednostavne dekoracije, dok su na drugom katu tri monofore i dvije trifore, daleko bogatijeg ukrasa.

Gotički pročelni otvoriljetne palače Paladinić osobiti su u svojem oblikovanju. Gotička monofora ili polifora upisana u pravokutni okvir poznata je od samog početka stambene gotičke arhitekture u Veneciji, a svoj izvor ima u daleko starijim slojevima bizanto-venecijanske umjetnosti. Dapače, četverolisni otvori u segmentnom isječku između luka

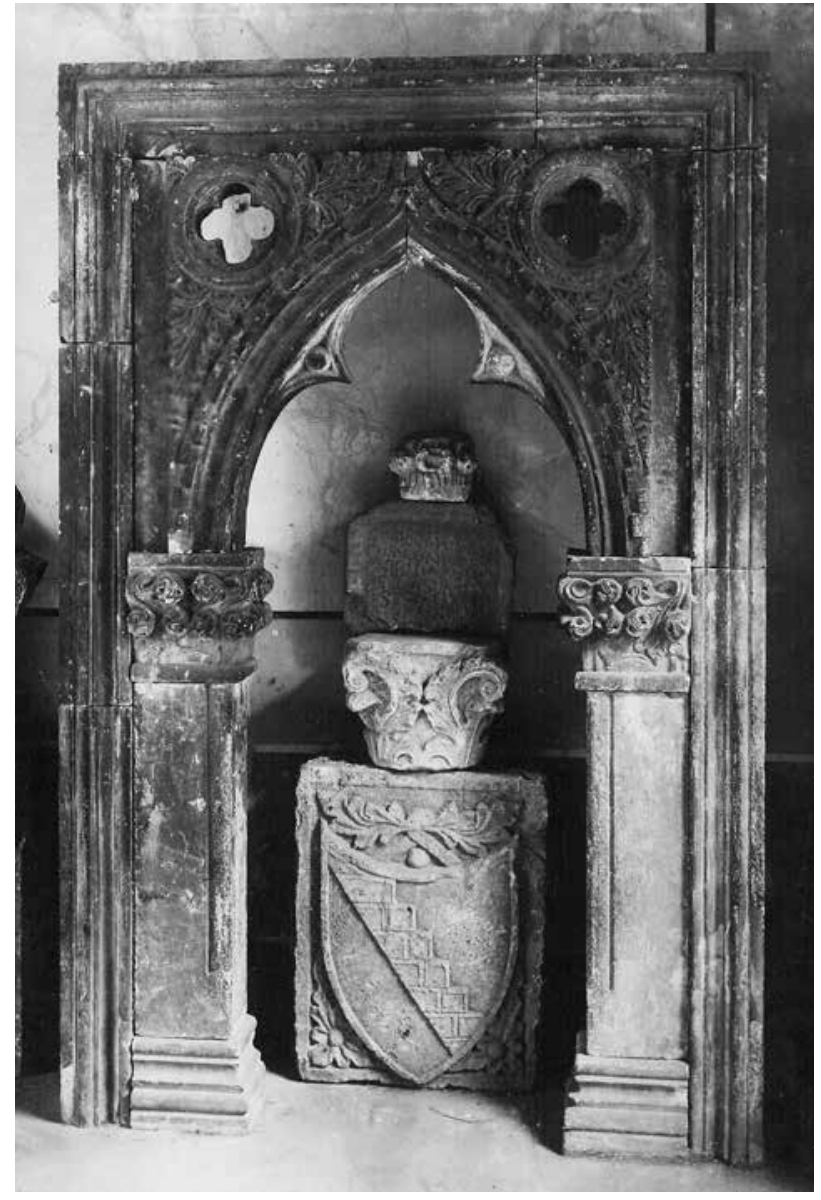

Gradski lapidarij u Korčuli, razdoblje između dva svjetska rata, kasnogotička monofora / Municipal lapidarium in Korčula, period between the Two World Wars, Late Gothic one-light window

i okvira odjek su smještaja okrugle patere upravo na istom mjestu kao u mletačkim primjerima. No, pravokutni okvir je u mletačkim primjerima daleko viši od vrha upisanog luka čime je postizana tipično gotička izduženost cjeline pročelnog otvora. Monofore te dvije trifore na primjeru ljetne palače Paladinić su drugačije. Tjemeluka udara u pravokutni okvir te je cjelina otvora znatno niža i zbijenija. Slični otvori javljaju se u Hvaru na kućama Užižić, Gazarović, zimskoj palači Paladinić, a ono što razlikuje gotičke otvore ljetne palače Paladinić od navedenih primjera je pojava spomenute četverolisne perforacije u gornjim uglovima pravokutnog okvira, preciznije u isječku između luka i okvira.

Drugi kat kuće Gargurić u Hvaru, vjerojatno izvorno de Magistris, pokazuje izrazite sličnosti s izvornim stanjem drugog kata ljetne palače Paladinić. Kako je u literaturi već uočeno, oba su rada zasigurno djelo istog autora koji djeluje pod utjecajem Jurja Dalmatinca. Naime, osim uobičajenih motiva povezuje ih kvalitetno izrađen ukras kovrčavog lista, tipičan za djela velikog majstora na istočnoj obali Jadrana. ${ }^{43}$

Osim hvarskih primjera, slične monofore s četverolisnom perforacijom u uglovima okvira su rijetke. Poznata 


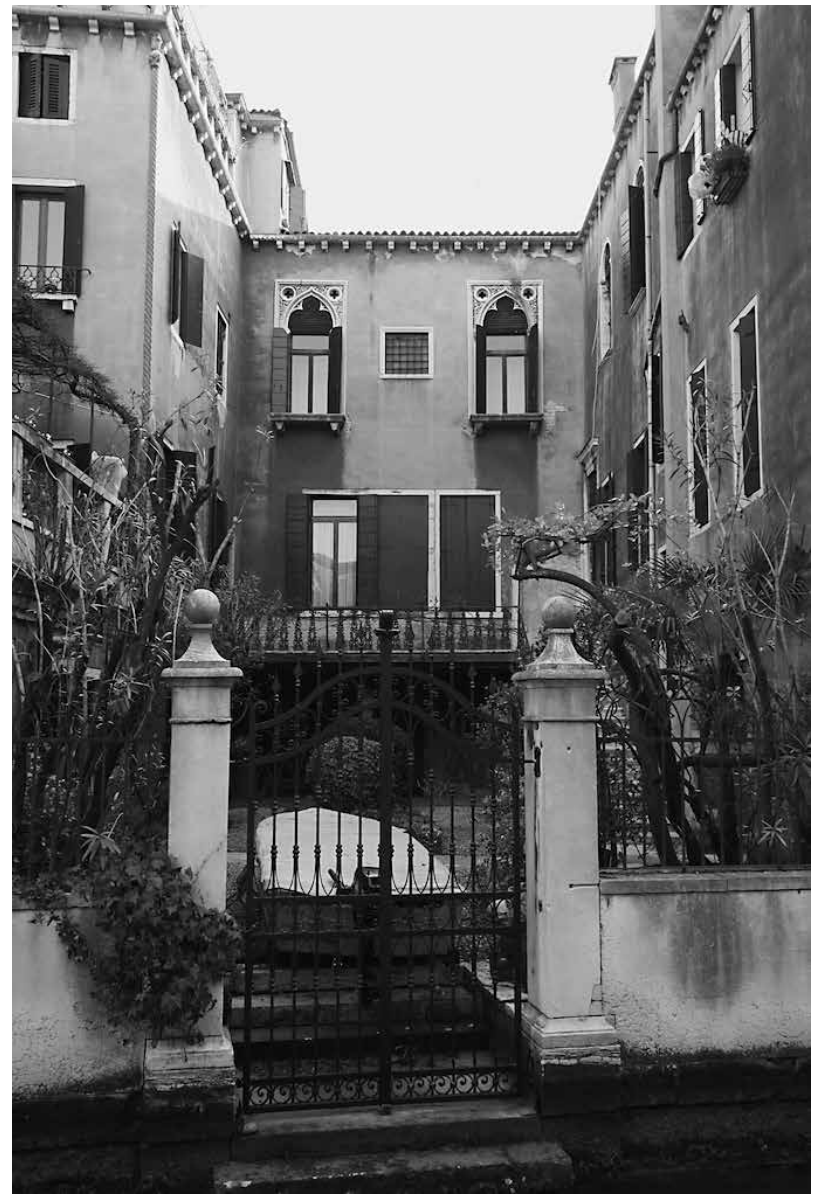

Kuća na Fondamenta van Axel o de le Erbe u Veneciji, dvorišno pročelje / House on the Fondamenta van Axel o de le Erbe in Venice, courtyard front

su dva primjera iz Korčule koja su do iza Drugoga svjetskog rata čuvana u gradskom lapidariju, a nije poznato na kojoj su kući izvorno stajala. Danas su uzidana na jednoj kući na šetalištu Petra Kanavelića. ${ }^{44}$ Izrazito su slična hvarskim radovima iako ne tako kvalitetno izvedenoga florealnog ukrasa. Zanimljivo je da se na jednoj monofori u Korčuli umjesto četverolisnog otvora pojavljuje trolisni.

Posve slične monofore nalazi se i u Veneciji gdje su također jedinstvene. Kuća se nalazi na Fondamenta van Axel o de le Erbe, a ulaz je iz Calle de le Erbe, 6110, 6111, 6120. Svi pročelni otvori te kuće uokvireni su tek plošno obrađenim kamenih gredama sizraženim potprozornicima oslonjenim na konzole. Ukrašen je tek kameni oluk oslonjen na konzole. Kuća je izvorno jednostavna gotička gradnja 15. stoljeća koja je u 19. stoljeću zasigurno doživjela veće preinake. No ovdje su zanimljive dvije monofore na drugom katu pročelja otvorenog prema dvorištu pred kanalom. Okvir ovih prozora posve je različit od hvarskih i korčulanskih primjera. Na mletačkim primjerima okvir prozora je tanak, plošnih profilacija i ukrašen malenim šiljcima, dok je to kod dalmatinskih primjera daleko masivniji niz gotičkih profilacija.

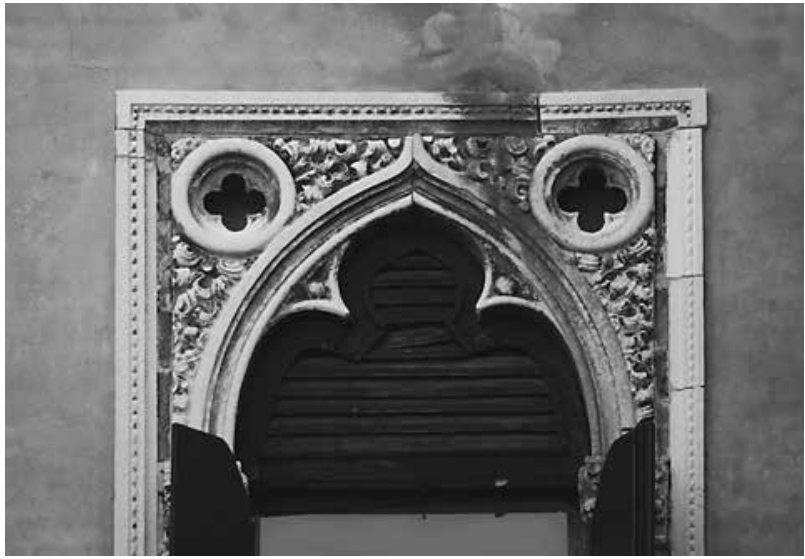

Kuća na Fondamenta van Axel o de le Erbe u Veneciji, dvorišno pročelje, detalj monofore drugog kata / House on the Fondamenta van Axel o de le Erbe in Venice, courtyard front, detail of second floor one-light window

Također se razlikuju i po pojavi izraženog potprozornika na konzolama kojeg kod dalmatinskih primjera nema. No trolisno oblikovani lukovi prozora sa segmentnim isječkom ukrašenim florealnim motivima i kvadriforama u kamenom prstenu posve su identični dalmatinskim primjerima. Kapiteli s lisnim ukrasom također je posve sličan hvarskim i korčulanskom primjeru.

Bolji pogled na monofore u Veneciji pokazuje da one zapravo nisu izvorne na svome mjestu nego da su segmentni isječci naknadno ubačeni. To posebice pokazuje desna monofora (gledano prema pročelju) gdje je evidentno ubacivanje cigle u procjep između isječka i okvira monofore. Za pretpostaviti je da spomenuti segmentni isječci dolaze iz Dalmacije, jer su, koliko sam za dugih i čestih šetnji Venecijom mogao utvrditi, jedini takav primjer u tom gradu. Moguće dolaze s istoga nepoznatog mjesta u Korčuli odakle i monofore nekad davno zabilježene u gradskom lapidariju, no o ovome je teško nešto više reći bez detaljnijih istraživanja.

Na kraju se treba osvrnuti na razloge zbog kojih je došlo do rekompozicije glavnog pročelja ljetne palače Paladinić. Spomenuto je da je riječ o jednom od čelnih ljudi hvarskih autonomaša, koji je imao velikih zasluga i za vođu njihova liberalnog krila u Dalmaciji, Lapennu. ${ }^{45}$ Prilikom preuređenja palače do izraza je došlo političko uvjerenje investitora: umjesto asimetričnih pročelja istočnog Jadrana, pojavila se simetrična, mletačka kompozicija pročelja. Kod Domenica Gazzarija politika je igrala veliku ulogu u životu. Podiže ljetnikovac s perivojem na lokalitetu Vrh istočno od Velog Grablja i tamo svoju grobnicu s nadgrobnim spomenikom u obliku piramide. Naime, s ovog se osamljenog i pustog mjesta često vidi Italija, obrisi brda Monte Gargano, a što Domenicu Gazzariju zasigurno nije bilo nevažno. Neženja, deklarirani ateist, iskreni liberal, doista zaslužan liječnik koji 
je 1856. godine zaustavio epidemiju kolere u Starom Gradu (potom od državne nagrade dao da se popločaju starigradske ulice), kuće je ostavio Antunu Bogliću, bliskom prijatelju, također iskrenom autonomašu.

Posve tiho, danas jedva čitljivo, ljetna palača Paladinić svojim naknadnim pročeljem prema Pjaci svjedoči o žestokim političkim borbama iz vremena svoje preinake. No, govori i o tome da laži nisu mnogo pomogle.

\section{BILJEŠKE}

1 Nije poznato kada je palača prepoznata kao ljetna no već se na jednoj razglednici iz oko 1900. godine palaču naziva »Palazzo Paladini estivo«. 2 NADA GRUJIĆ, Vrijeme ladanja-Gučetićev ljetnikovac u Trstenom, Dubrovnik, 4 (1994.), 82; JACQUES LE GOFF, Civilizacija srednjovjekovnog zapada, Golden marketing, Zagreb, 1998., 390; FERDINAND BRAUDEL, Sredozemlje i sredozemni svijet u doba Filipa II., sv. II, Antibarbarus, Zagreb, 1997., 261; CVITO FISKOVIĆ, Prilog poznavanju ishrane 16. i 17. stoljeća u Dalmaciji, Adrias, 1 (1987.), 16-17.

3 JOŠKO KOVAČIĆ, Uz prošlost hvarske Pjace, Građa i prilozi za povijest Dalmacije, 13 (1997.), 67. U ovom se radu ponavlja ocjena N. Dubokovića Nadalinija da je Pjaca prije svega poljana između dvije aglomeracije, što je samo djelomično točno i to ponajprije u starijim razdobljima kada se i naziva ravnicom ili trgom, primjerice 1420. godine, terra plana seu planices, aut plathea. Zanimljive su sličnosti hvarske Pjace s trogirskim gradskim trgom. Vidi: IRENA BENYOVSKY, Trogirski trg u razvijenom srednjem vijeku, Povijesni prilozi, 16 (1997.), 11-32.

4 DANIELE FARLATI, Hvarski biskupi, preveo K. Lučin, Mogućnosti, 1-3 (1999.), 142.

5 Item de horto haeredum Sovignae Balcii, sito ad Civitatem Novam prope murum communis, sunt passa duo et medium communis a parte levantis.

Item de horto Stephani Vidossii, sito ad Civitatem Novam prope murum communis, sunt passa duo communis, videlicet passum unum a parte ponentis et passum unum a parte meridiei.

Item de horto haeredum Bogdani Cumulcii, sito ad Civitatem Novam prope murum communis, sunt passa duo communis, videlicet passum unum a parte meridiei et passum unum a parte levantis.

Item de horto ser Mixae Jaxae, sito ad Civitatem Novam prope puteum, sunt passa duo vel circa communis.

Item de horto ser Mixae Jaxae, sito ad Civitatem Novam prope iura haeredum Nicolae Bogdani, sunt passa duo communis a parte transversae.

Item de horto Zvitchi Rafalich, sito ad Civitatem Novam prope hortum ser Mixae Jaxae, est passum unum et medium communis a parte transversae. Item de horto ser Vidosii Deschi, sito ad Civitatem Novam prope suprascriptos hortos, sunt passa tria communis, videlicet unum a parte meridiei et a parte levantis duo.

Item de horto Maratini Pecussini sito prope suprascriptos hortos, est passum unum communis a parte ponentis.

Item de horto donnae Dessae Orlandi, sito prope suprascriptos hortos, est passum unum communis a parte ponentis.

Item de horto Stipoy Obradich, sito prope suprascriptos hortos, est passum medium communis a parte levantis.

Item de horto Marini Ragusini, sito prope murum civitatis, est passum medium communis a parte levantis.

Item de horto donnae Dessae Orlandi, sito prope portam civitatis, sunt passa tria communis a parte ponentis.

Johannes Vidossii occupavit de terreno communis in suo horto sito prope puteum a parte transversae brachia duo. Monumenta historico-juridica Slavorum Meridionalum, Pars I., Statuta et Leges, Volumen III. Statuta et leges Civitatis Buduae, Civitatis Scardonae et Civitatis et Insulae Lesinae, Zagabriae, 1882.-1883., 335-336.
6 Pavao Paladinić ovdje nastupa kao zastupnik hvarskog biskupa Tome Tomasinija koji zasigurno ima važnu ulogu u donošenju ovog dokumenta, odnosno oblikovanju Pjace kao središnjega gradskog trga. JOŠKO KOVAČIĆ (bilj. 3), 93.

7 Dokument je objavljen u JOŠKO KOVAČIĆ (bilj. 3), 93-95. Zanimljivo je da, vjerojatno potaknuta zahtjevom arhiđakona Paladinića, komuna 1466. godine donosi odluku o granicama gradskih putova i vrtova. MIRKO ZJAČIĆ, Regeste pergamena XV. vijeka Kaptolskog arhiva u Hva$r u$, Bilten Historijskog arhiva komune hvarske, 7-8 (1965.), 18.

8 Slična odluka ponavlja se 1537. godine kada i hvarski knez i providur Cornelije Barbaro zabranjuje gradnju kod lože, komunalne palače, škvera i kuće Frane Gariboldija, »... tam super saligo poenes logiam et palatium quam super schero prope mare et habitationem ser Francisci Gariboldi...« DUŠAN BERIĆ, Arhivi otoka Visa, Arhiv grada Splita, Split, 1958., 18.

9 JOŠKO KOVAČIĆ (bilj. 3), 94.

10 JOŠKO KOVAČIĆ (bilj. 3), 72.

11 CVITO FISKOVIĆ, Još o palmi u našoj hortikulturnoj baštini, Hortikultura, 1-2 (1983.), 3; MARINKO PETRIĆ, Veduta Hvara iz 1486. g., Prilozi povijesti otoka Hvara, 7 (1983).

12 VINKO FORETIĆ, Građa o srednjodalmatinskom području u arhivu korčulanske obitelji Arneri, Građa i prilozi za povijest Dalmacije, 11 (1990.), 108.

13 STIJEPO PLANČIĆ, Inventar Arhiva Hektorović, III. dio, Centar za zaštitu kulturne baštine, Hvar, 1984., 245. Ta se kuća 1449. godine spominje u vlasništvu Nikole Užižića. JOŠKO KOVAČIĆ, $O$ kući $t z v$. Hektorović na gradskom zidu u Hvaru, Prilozi povijesti otoka Hvara, 10 (1997.), 85.

14 STIJEPO PLANČIĆ (bilj. 13), 214. Slično mnogim drugim nekretninama i o tim se vrtovima razvila duža parnica između obitelji Paladinić, Barbis, Hektorović i drugih. U Arhivu Hektorović sačuvan je cijeli jedan svezak, broj 137, o ovom sporu. Matij Hektorović i njegov sin Markantun sporili su se još početkom 18. stoljeća o pravima prolaza uz ove vrtove. STIJEPO PLANČIĆ, Inventar Arhiva Hektorović, II. dio, Centar za zaštitu kulturne baštine, Hvar, 1982., 8, 53.

15 STIJEPO PLANČIĆ (bilj. 14, 1982.), 48.

16 PETAR HEKTOROVIĆ, Prijepis oporuke Petra Hektorovića iz 1572. godine, Djela Petra Hektorovića, (ur.) Josip Vončina, Hrvatska akademija znanosti i umjetnosti, Zagreb, 1986., 144.

17 PIETRO PAZZI, I cavalieri di San Marco: Storia documentata, Perasto, 2008., 109-110.

18 ANDRO GABELIĆ, Ustanak hvarskih pučana: izvori, tokovi, domet, Književni krug, Split, 1988., 577. U arhivu Arneri u Državnom arhivu u Dubrovniku (I-1/2, 30-C, 31.) čuva se spis Historia della vittoria con sette fuste turchesche fatta da Nicolo Paladini SIgnor Sopracomitto.di Galera Lesignana a Rodi dell' i474. 3 Novembre. Svu težinu plemićko-pučkih odnosa u buni pokazuje objašnjenje pučana o ubojstvu plemića. Oni su bez puno kajanja konstatirali da ih je zadesila zla kob.

19 SANTE GRACIOTTI, Il petrarchista dalmata Paolo Paladini e il suo canzoniere (1496), Il calamo, Roma, 2005.

20 JOŠKO KOVAČIĆ, Kroz hvarsko stambeno graditeljstvo, Iz hvarske kulturne baštine, Hvar, 1987., 55.

21 Prijepis dokumenta iz fonda obitelji Paladinić u Zadru čuva se u Biblioteca Nazionale Marciana, Archivio Praga, MSS Italiani, Classe VI. Pietro Ettoreo, Scrittura volgare in causa contro un Paladini per la costruzioni di un castello a Lesina (1524). Cod. 542, XXXVIII, 12336; IVO ŠTAMBUK, Kuća Marina Hektorovića pok. Hektora i njegovog sina pjesnika Petra, Prilozi povijesti otoka Hvara, 10 (2002.), 128.

U citiranom radu I. Štambuka donesen je prijevod izvornog teksta P. Hektorovića koji je Joško Belamarić preveo i objavio u časopisu Zarez pod naslovom Petar Hektorović - Spor protiv Franje Paladinija zbog gradnje torete uz njegovu ljetnu palaču na hvarskoj Pjaci 1524. godine. Tekst J. Belamarića je bez izmjena i pod imenom stvarnog autora donesen kao prilog teksta I. Štambuka. Prijevod izvornog teksta u ovom radu donesen je prema prijevodu J. Belamarića koji je publiciran u navedenom tekstu I. Štambuka. 
22 JOŠKO BELAMARIĆ (bilj. 21), 132.
23 JOŠKO BELAMARIĆ (bilj. 21), 133.

24 Zavod za povijesne znanosti HAZU u Dubrovniku, Arhiv Hektorović, svezak 110/9.

25 JOŠKO BELAMARIĆ (bilj. 21), 132.

26 JOŠKO BELAMARIĆ (bilj. 21), 133.

27 JOŠKO BELAMARIĆ (bilj. 21), 134.

28 JOŠKO BELAMARIĆ (bilj. 21), 137.

29 Rješenje s palače Paladinić Fisković je u minucioznosti usporedio s vrtom na kojem su podignuti stupići odrine na shodu između korčulanske katedrale i zgrade Biskupskog dvora koji je podigao biskup Frano Manola. CVITO FISKOVIĆ, Južnohrvatske dalmatinske odrine 16.-19. stoljeća, Hortikultura, 1-4 (1994.), 5.

30 JOŠKO BELAMARIĆ (bilj. 21), 136.

31 Slično Hektoroviću ili Paladiniću i drugi plemići uzdignuli su sredinom 15. stoljeća svoje kuće na južni gradski zid, što je bilo protuzakonito i što je dovelo do brojnih prosvjeda pučana. Njihovo izdizanje iznad zatvorenog tkiva srednjovjekovnog grada i osvajanje sunčanih i otvorenih prostora iznad zidina također u svojoj osnovi ima traženje ladanjskog doživljaja prostora. Njihovi podizaoci imali su humanističko zaleđe: 1464. godine Petar Užižić traži dozvolu za gradnju svoda od kuće do južnoga gradskog zida, a gdje kaže da će podići luk alla romana, a istih godina u govoru mletačkom knezu o problemu uvoza žita koristi cijeli niz antičkih literarnih toposa. Luk koji podiže Petar Užižić, segmentni polukružni luk, i danas sačuvan, prvi je poznati renesansni oblik u Hvaru, a slični se lukovi zidaju i na klaustru franjevačkog samostana koji se tih godina počinje podizati. NIKŠA PETRIĆ, Sukobi plemića i pučana kroz izgradnju grada Hvara, Radovi Instituta za hrvatsku povijest, 10 (1977.), 447-453; JOŠKO KOVAČIĆ (bilj. 13), 85.

32 HANIBAL LUCIĆ, Robinja, prijevod i komentari Marko Grčić, Grafički zavod Hrvatske, Zagreb, 1988., 134-135.

33 JOŠKO KOVAČIĆ, Razvoj grada i luke Hvara kao vojnog i pomorskog središta, Građa i prilozi za povijest Dalmacije, 25 (2012.), 289.
34 Državni arhiv u Zadru, fond Znanstvena knjižnica u Zadru, Documenti che si riferiscono al posesso patrimoniale della famiglia Paladini di Lesina, sig. 15213, MS 273.

35 Ratni arhiv u Beču, Inland C III, a, Lesina, Nr. 17.

36 Državni arhiv u Splitu, Mapa karata za Istru i Dalmaciju, K. o. Hvar

37 JOŠKO KOVAČIĆ, Crkva Svih Svetih na Pjaci, Iz hvarske kulturne baštine, Hvar, 1987., 271.

38 JOŠKO KOVAČIĆ, Gradnje i prigradnje kuća u Hvaru od 1813. do 1948. godine, Građa i prilozi za povijest Dalmacije, 19 (2003.), 169-170.

39 Muzej hvarske baštine, Mali fondovi, 379a, 423. Dva detalja prerisa iz 1925. godine objavio je N. Duboković Nadalini 1961. godine. Riječ je o kratkom, preglednom radu bez bilješki, u kojem su objavljene dvije podosta mutne fotografije glavnoga, južnog pročelja te tlocrt drugog kata. Duboković objavljuje nacrte koji se nalaze u arhivu Ivanić-Bogli-Božić, dok se ovdje donose prerisi iz nekadašnjega građevinskog arhiva općine Hvar. NIKO DUBOKOVIĆ NADALINI, Gotička palača na trgu u Hvaru, Bilten Historijskog arhiva komune hvarske, 3-4 (1961.), 30-33.

40 Više o obiteljima Boglić i Božić u JOŠKO KOVAČIĆ, Obitelj i arhiv Boglić-Božić u Hvaru, Prilozi povijesti otoka Hvara, 11 (2002.), 155-171. 41 CIRILLO M. IVEKOVIĆ, Dalmatiens Architektur und Plastik, band VI.-VIII., Wien, 1910, 291/2.

42 JOŠKO KOVAČIĆ (bilj. 37), 172.

43 AMBROZ TUDOR, Prilog poznavanju utjecaja Jurja Dalmatinca $u$ Hvaru, Peristil, 41 (1998.), 52.

44 Zahvaljujem na informacijama kolegici Mariji Kraljević.

45 O D. Gazzariju: PIETRO CONFALONIERI, Dr. Domenico Gazzari, Spalato, 1882.; NIKŠA STANČIĆ, Otok Hvar u vrijeme hrvatskog narodnog preporoda u XIX. stoljeću, MIRO MIHOVILOVIĆ et al., Otok Hvar, Matica hrvatska, Zagreb, 1995., 109-117; ŽARKO GAZZARI, Tragovima Slavogosta: rodoslovlje i povijest hvarske porodice Gazarović-Gazza$r i$, Književni krug, Split, 2002., 28-33. U radu Ž. Gazzarija objavljen je epigraf na grobu D. Gazzarija koji je sastavio njegov prijatelj i nasljednik Antun Boglić. 
Summary

Ambroz Tudor About the Original Appearance of the Paladinić Family Summer Palace
on the Piazza in the City of Hvar

The lower or summer Paladinic Palace is situated in front of the south stretch of the city, in a place which had been dominated by gardens throughout the centuries. It was built in the second half of the 15th century, probably by Nikola Paladinić, Knight of Saint Mark. The upper or winter Paladinić Palace was built on the city walls, facing the summer residence, divided from it by a park which was planted with orange trees in the 17th century. In the course of centuries the summer palace had a succession of owners. In the 17th century it housed a Venitian military hospital, in the second half of the 18th century it became the first café in Hvar. In the years 1524 - 1525 Fran Paladinić and the great Renaissance poet Petar Hektorović faught in court over a small torretta, which Paladinic had built on the north-east front of his summer palace.

In the 19th century the house was owned by Domenico Gazzari, a surgeon and leader of the autonomists of Hvar. In 1868 - 1869 he undertook the reconstruction of his palace, to repair damages probably caused by its unstable foundations. A document, kept in the Hvar Heritage Museum, has the copy of the original plan of the reconstruction of the building, conceived by the builder Vicko Kovačević from Hvar. This document also records the state of the palace before and after the reconstruction. The greatest change made in its interior is the insertion of a spiral staircase and a corridor on each floor. However, the principal alteration occurred on the south front of the Palace, facing the city piazza. The original front was asymmetrical, like most Late Gothic fronts in Dalmatia. In the reconstruction of 1868 - 1869 the south front was "symmetrized", made to resemble Venetian housefronts. 